AperTO - Archivio Istituzionale Open Access dell'Università di Torino

Evaluation of the efficacy of insecticidal coatings based on teflutrin and chlorpyrifos against Rhynchophorus ferrugineus

This is a pre print version of the following article:

Original Citation:

Availability:

This version is available http://hdl.handle.net/2318/1664230

since 2020-04-03T18:39:20Z

Published version:

DOI: $10.1002 / p s .4527$

Terms of use:

Open Access

Anyone can freely access the full text of works made available as "Open Access". Works made available under a Creative Commons license can be used according to the terms and conditions of said license. Use of all other works requires consent of the right holder (author or publisher) if not exempted from copyright protection by the applicable law. 


\section{Summary} 2 3 4

\title{
Evaluation of the efficacy of insecticidal coatings based on teflutrin and chlorpyrifos against Rhynchophorus ferrugineus
}

\author{
Pugliese Massimo*, Rettori Andrea Alberto*,**, Martinis Roberto***, Al-Rohily Khalid***, Al- \\ Maashi Ali*** \\ * AgriNewTech srl, Via G. Quarello 15/A, 10135 Turin, Italy; \\ ** Studio Associato Planta, Via Chiesa 19, 10090 Rosta (TO), Italy; \\ *** Saudi Basic Industries Corporation, PO Box 5101, KSA-11422 Riyadh, Kingdom of Saudi \\ Arabia
}

The date palm (Phoenix dactylifera L.) is an important economic resource for many nations worldwide, recently threatened by the presence of different insect pests, like the red palm weevil (RPW) Rhynchophorus ferrugineus. Different strategies to control the insect have been used so far worldwide, including insecticides, biological control, endotherapy and pheromones, but it is still causing serious damages to palms in several Countries. In the present study, a new approach has been used to control the insect, based on a non-phytotoxic and non-toxic coating material applied on palm trees to prevent the red palm weevil attacks. Two products, a glue (polyvinyl acetate) and an oil (raw linseed oil), have been used as coatings and applied together with a repellent and two insecticides (teflutrin and chlorpyrifos) at different dosages on 2 species of palm (Phoenix dactylifera and Phoenix canariensis). Phytotoxic effects of the treatments have been evaluated in greenhouse on 260 potted palms (130 Phoenix dactylifera and 130 P. canariensis) and no negative effects have been observed. Afterwards, a trial lasting 400 days has been carried out in a nursery located in Sicily (South Italy), treating 572 potted palm trees (286 P.dactylifera and $286 P$. canariensis) with an average diameter at base of $18-20 \mathrm{~cm}$. After 400 days, $48 \%$ of the untreated palms were infested, while only $3 \%$ of date palms and $7 \%$ of Canary palms treated with insecticide at lower dosages have been infested. The application of an insecticide based coating is a good strategy to control and prevent the red palm weevil infestation, in particular on date palms.

Keywords: Rhynchophorus ferrugineus; teflutrin; chlorpyrifos; polyvinyl acetate; coating. 
Rhynchophorus ferrugineus Olivier (Red Palm Weevil - RPW), a native pest of South and South East Asia, causes serious and important crop and landscape damage attacking date palms and other palm species in many parts of the world (EPPO, 2007). The male and female adults of this insect, member of Coleoptera: Curculionidae, are large reddish brown beetles about $3 \mathrm{~cm}$ long and with a characteristic long curved rostrum. Due to their strong wings, they are capable of undertaking long flights (Salama et al., 2009).

Damage to palms is produced mainly by the larvae. Adult females lay about 200 eggs at the base of young leaves or in wounds to the leaves and trunks; the grubs feed on the soft fibers and terminal bud tissues. They reach a size of more than $5 \mathrm{~cm}$ before pupation. Except just before pupating, they move towards inner tissues of the palm tree making tunnels and large cavities damaging its internal tissues. The larvae can be found anywhere within the palm, even in the very base of the trunk where the roots emerge. This burrowing weakens and eventually kills the tree. Although adult weevils can damage trees by feeding on them, larvae can cause greater damage by burrowing. The complete life cycle of the insect takes an average of 82 days (Murphy and Briscoe, 1999), up to 93 (Salama et al., 2009) and 124 (Kaakeh, 2005), depending on different feeding substrate. They can be found in any place within the palm (Alkhazal et al., 2009) from the base of the trunk where the roots emerge up to the apical bud. Vertical distribution of infestations along the trunk of date palm trees generally showed that $70 \%$ of the attack occurred from the ground up to $1-1.5 \mathrm{~m}$. On other palm trees (i.e. Phoenix canariensis) the attacks occur principally near the apical bud (80$90 \%)$.

In 1994, this past had been captured in the south of Spain and it was observed in Italy later in 2004 (Vacante, 2013). Today, it can be found in almost all Mediterranean countries (EPPO, 2008). The spread of this pest occurs due to transporting infested young or adult date palm trees and offshoots from contaminated to uninfested areas.

The external symptoms on infested palm trees are a progressive yellowing of the leaf area, destruction of the rising leaf and necrosis in the flowers. Leaves begin to dry in ascending order in the crown; the apical leaf bends and eventually drops. Affected plant tissue turns foul, producing strong characteristic odours (EPPO, 2007). Infested palms generally do not show any obvious early symptoms, and usually the weevil is detected only after most damage has been caused on the palm, and preventive measures are mostly indicated to control it (Kehat, 1999). Preventive and curative measures include: trunk injection with systemic insecticides; treatment of wounds with repellents; drenching of the crown of infested trees 
with insecticides (EPPO, 2008). Control of the red palm weevil is problematic and particularly challenging for several reasons, even with pesticides. Adults are mobile and easily bypass or evade containment barriers thereby expanding infestation outbreaks. Moreover, the pest is concealed deep inside palm trunks and consequently insecticides have to be applied frequently and over a long period (Faleiro, 2006; Llácer et al., 2010; Murphy and Briscoe, 1999). In addition, a restriction in the use of insecticides has occurred recently due to concerns about the side effects of chemical pesticides on the environment. Systemic insecticides may be the best chemicals available for controlling the RPW, also once palms are already infested (Llácer et al., 2012) and are also applied successfully with endoterapy and trunk injection, with concerns about residues on dates.

Natural enemies do not play an important part in controlling $R$. ferrugineus (Reginald, 1973) and at present there is no practical biological control. However, pheromones are increasingly used against $R$. ferrugineus and protocols for pheromone-based mass trapping of the weevil have been developed (Hallett et al., 1999).

Only in few cases, like in Israel, the eradication of the insect, detected in 1999, was achieved in 4 years by implementing several measures such as mass trapping, chemical treatment of infested palms, destruction of heavily infested palms and preventive measures (Hamburger et al., 2003). Similarly in Morocco and Tunisia (Vacante, 2013).

Considering the widespread presence of RPW and the difficulties to control it, a new approach has been applied to prevent palms infestation based on the use of non-phytotoxic and non-toxic coating material applied on palm trees to prevent the attacks.

\section{Materials and methods}

\section{Treatments}

Two products, a glue (polyvinyl acetate, Vinavil 59, Vinavil Spa, Italy) and an oil (raw linseed oil, Linoil, Chimica C.B.R. Spa, Italy), have been used as coatings and applied together with a repellent (camphor) and two insecticides, teflutrin (Teflustar, 0.2\% p.a.) and chlorpyrifos (Zelig GR, 7.5\% p.a.) at different dosages on 2 species of palm (Phoenix dactylifera and Phoenix canariensis).

Tefluthrin is one of the most toxic pyrethroids, while chlorpyrifos is a toxic crystalline organophosphate insecticide that inhibits acetylcholinesterase.

The mixtures of products applied in the trials are listed in Table 1.

\section{$\underline{\text { Phytotoxicity evaluation }}$}

Seven years old $P$. dactylifera and 5 years old $P$. canariensis have been used and totally 260 potted palms (n. 130 P. dactylifera and n. 130 P. canariensis) have been treated and placed in greenhouse 
to assess the phytotoxicity of the selected products. The average diameter at the base was respectively $9.5 \pm 2.6$ and $8.5 \pm 1.6 \mathrm{~cm}$. Ten palm trees per species have been treated for each product mix. Products have been applied by painting, to avoid the drift of pesticides in an enclosed place (greenhouse).

Phytotoxic effects have been evaluated with a monthly visual assessment observing the presence/absence of leaves discoloration or necrosis (scale: $0=$ no symptoms; $1=$ light leaf chlorosis or necrosis; $2=$ leaf chlorosis or necrosis up to $25 \% ; 3=26-50 \%$ leaf chlorosis or necrosis; $4=51$ 90\% leaf chlorosis or necrosis; $5=$ plant death),.

At the same time of visual assessment other measurements have been carried out:

- Thickness measurements of the films applied (3 measurements/leaf on three leaves coated portion for each plant) with Positector 200-ultrasonic coating thickness gage.

\section{Efficacy evaluation}

The nursery activities took place between August 2013 and the end of November 2014.

After two months of acclimatization, treatments were carried out in October 2013 and repeated in November 2013 on 572 palm trees (286 P. dactylifera and 286 P. canariensis). The two species have been positioned in two separate blocks. The distance of each palm from the others was 1 meter. Date palms were from 9 to 13 years old, with average diameter at base $20.1 \pm 5.4 \mathrm{~cm}$; Canary palms were from 7 to 8 years old with $17.8 \pm 1.8 \mathrm{~cm}$ diameter. Treatments have been carried out randomly inside the two blocks of palms at 14-16 October 2013, the coatings have been applied by brush and by spray (Black \& Decker - SmartSelect HVLP Sprayer mod. BDPH400). Sicily) were carried out to characterize plant physiology and coating application, in order to assess the efficacy of the products to prevent RPW infestation and to test the efficacy of the curative effect. 
137 Forty-four palm trees not treated (22 P. dactylifera and 22 P. canariensis) served as control. In the 138 months of August and September 2013 irrigations were made every 2 days, in October every 4 139 days, from November 2013 to March 2014 every 7 days and from April to September 2014 every 3 140 days. Fertilizations have been made in October 2013, in May 2014 and in October 2014 using a 141 ternary fertilizer (COMPO NPK Original Gold®, 5-10 g per pot).

142 The average temperature of whole period has been $18^{\circ} \mathrm{C}$. Maximum temperatures were recorded in 143 the months of July, August and September and were about 40 degrees.

144 At the end of November 2014 all the palms involved have been sectioned to verify the real 145 infestation. Each palm tree has been cut by chainsaw at the base about 2-4 cm height.

Data analysis

About the phytotoxicity evaluation ANOVA with Tukey's HSD $(\mathrm{p} \leq 0.05)$ has been applied. About the efficacy, infested palms were calculated as percentage, where healthy palm corresponds to 0 and infested palm to 100 . ANOVA with Tukey's HSD $(\mathrm{p} \leq 0.05)$ has been performed.

\section{Results and discussion}

154 The average thickness at the end of trials was $0.257 \pm 0.088 \mathrm{~mm}$ for vinyl acetate and $0.091 \pm 0.023$ $\mathrm{mm}$ for raw linseed oil in the greenhouse trial, $0.135 \pm 0.038 \mathrm{~mm}$ for vinyl acetate and $0.072 \pm 0.032$ $\mathrm{mm}$ for raw linseed oil in the nursery trial. At the end of phytotoxicity test, after 7 months, the absence of damages on treated potted palms were confirmed: no phytotoxic effects have been observed (Table 2). For each treatment and for each parameter no significant differences were observed during the months. In particular, no statistical difference have been observed comparing the treatments to the untreated control in terms of chlorophyll content (CCI), leaf discolouration and necrosis.

162 Regarding the trial in Sicily, 71 palms out of 572 were infested (36 date palms and 35 Canary palms) after 400 days from the treatments:

- 21 controls (not treated): 13 Date palms and 8 Canary palms;

- 32 palms treated with liquid suspensions insecticide-free;

- 11 with vinyl acetate based products (5 with Camphor and 6 without Camphor);

- 21 with raw linseed oil based products (10 with Camphor and 11 without Camphor); concentration; 
- 2 palm treated with vynil acetate solution containing insecticide (Teflutrin) at high concentration;

- 4 palm treated with oil solution containing insecticide (Teflutrin) at low concentration;

- 2 palm treated with oil solution containing insecticide (Teflutrin) at high concentration;

- 3 palm treated with oil solution containing insecticide (Chlorpyrifos) at low concentration;

- 4 palm treated with oil solution containing insecticide (Chlorpyrifos) at high concentration.

Some infested palms were completely decayed or hollow and all stages of RPW were found (young and old larvae, adults).

The treatments containing insecticides reduced the infestations, but after 400 days they were losing their efficacy. The best results have been achieved with vinyl acetate and chlorpyrifos at both dosages (T5 and T6) and no infestation have been observed after 400 days. In the case of linseed oil and teflutrin or chlorpyrifos at high dosage (T7 and T9), no infestation have been observed after 323 days. For the combinations vinyl acetate and teflutrin at both dosages (T2 and T3), and linseed oil and teflutrin or chlorpyrifos at low dosage (T8 and T10) no infestation have been observed after 245 days.

After 400 days, 36 date palms were infested by RPW: 13 controls, 4 treated with vinyl acetate products (without insecticide), 1 treated with vinyl acetate product (with insecticide), 13 treated with raw linseed oil (without insecticide) and 5 treated with raw linseed oil (with insecticide) (Table 3). Vinyl acetate with teflutrin at higher dosage, vinyl acetate with chlorpyrifos at both dosages and raw linseed oil with teflutrin at higher dosage were able to prevent the infestations on date palms (Table 3).

After 400 days, 35 Canary palms were infested by RPW: 8 controls, 7 treated with vinyl acetate product (without insecticide), 4 treated with vinyl acetate product with insecticide, 8 treated with raw linseed oil with insecticide and 8 treated with raw linseed oil (without insecticide) (Table 3).

In the case of Canary palms, only the application of vinyl acetate with chlorpyrifos at both dosages was able to prevent the attacks on date palms (Table 3).

Comparing the results among the palms treated with linseed oil (with or without insecticides), vynil acetate (with or without insecticides) and untreated control, vinyl acetate generally reduced the infestation better than raw linseed oil (Tab. 4). Moreover, both vinyl acetate and linseed oil applied without insecticide were able to reduce the infestation (Tab. 4).

It seems that the vinyl coating without insecticide has a minimum repellent action, certainly greater than the coating with raw linseed oil. In fact, at the end of the trial, infested palms treated with raw linseed oil without insecticide are double respect those treated with vinyl (Tab. 5). 
203 The vinyl acetate coating with insecticide had the best efficacy. Regarding the insecticides, 204 Chlorpyrifos was more effective, but only if combined with the vinyl acetate. Tefluthrin also seems more effective combined with vinyl, especially in the long period (Tab. 6).

\section{Conclusions}

208 The treatments carried out had a positive effect on the health of the palms. After 400 days, 71 palm 209 trees were infested by RPW: 21 controls and 50 treated. Only $9.4 \%$ of the treated palms were 210 infested, compared to $47.7 \%$ of the untreated.

211 The first infestations on insecticide treated palms have been detected after 245 days, after that it 212 begins to lose effectiveness. The efficacy of the treatment is variable and depending on the time, the 213 presence and the type of active principle. The coatings with vinyl acetate and chlorpyrifos (T5 and 214 T6) seem to be the most effective (100\% up to 400 days in this test).

215 These products could be easily applied by airsprayer and the solution have been prepared and 216 immediately used. Treatments on adult palms could leave small areas not covered (especially with 217 not well pruned petioles) and therefore the possibility for RPW to penetrate would be higher compared to small plants. Based on information collected during the test, it can be assumed that a vinyl-based coating with an insecticide like chlorpyrifos could be used to significantly reduce the possibility of RPW infestation, providing a treatment every six months.

Similar results have been achieved by the use of the insecticidal paint Inesfly IGR FITO (Industrias

Quõ'micas Inesba S.L., Paiporta, Spain), having as active ingredients 3.0\% chlorpyrifos and $0.063 \%$ pyriproxyfen in a microencapsulated formulation (Llàcer et al., 2010). The coating application confers the advantage of releasing the active ingredients slowly, so the treatments do not need to be applied frequently and the effect can last for a longer time (Lòpez et al., 1999, Mosqueira et al. 2005, Amelotti et al. 2009). In our case, the coating was able to last 400 days, while the insecticidal paint Inesfly IGR FITO has been tested for 180 days (Llàcer et al., 2010). According to our results, the coating without chlorpyrifos was also initially effective, but of course this active ingredient is the primary cause of the efficacy of the product. Chlorpyrifos is widespread used to control insect pests and it is recommended to control $R$. ferrugineus in several countries within the Europe. However, it is not possible to apply the coating as curative effect on already infested palms, because the target pest is protected inside the palm, and other products are recommended, such as imidacloprid (Kaakeh, 2006), or biological control agents (Llàcer et al., 2009). The product can be applied within an integrated pest management strategy for $R$. ferrugineus which includes surveillance, early detection, trapping using pheromones, protecting wounds, physical methods, sanitation, use of attractants and other chemicals (Hoddle et al., 2013; Hussain et 
al., 2013). In particular the adoption of early detection method (Rettori et al., 2015) integrated with

238 vinyl acetate coating containing chlorpyrifos can be considered an optimal combination of methods 239 for IPM.

\section{REFERENCES}

- Alkhazal, M.H.; Youssef L.A.; Abdel-Wahaed M.S.; Kassab A.S.; Saleh M.M.E. (2009). Factors affecting infestation pattern of the red palm weevil, Rhincophorus ferrugineus Oliv. In date palm farm in Qatif, Saudi Arabia. Arab. Univ. J. Agric. Sci. Ain Shams Univ., Cairo, 17 (1) 177-183.

- Amelotti I., Català S. S., and Gorla D. E. (2009). Experimental evaluation of insecticidal paints against Triatoma infestans (Hemiptera: Reduviidae), under natural climatic conditions. Parasites Vectors 2, 30 (http://www.parasitesandvectors.com/content/2/1/30).

- EPPO (2007). Rhynchophorus ferrugineus and Rhynchophorus palmarum. Bulletin OEPP/EPPO Bulletin, 37(3), 571-579. http://www.blackwellsynergy.com/doi/full/10.1111/j.1365-2338.2007.01165.x

- EPPO (2008). Data sheets on quarantine pests Rhynchophorus ferrugineus. EPPO Bull. 38, 55-59.

- Faleiro J. R. (2006). A review of the issues and management of the red palm weevil Rhynchophorus ferrugineus (Coleoptera: Rhynchophoridae) in coconut and date palm during the last one hundred years. Int. J. Trop. Insect Sci. 26, 135-154.

- Hallett R. H., Oehlschlager A. C., Borden J. H. (1999). Pheromone-trapping protocols for Rhynchophorus ferrugineus. International Journal of Pest Management 45, 231-237.

- Hamburger M., Bitton S., Nakache J. (2003). Control of Rhynchophorus ferrugineus, a quarantine pest in Israel. Phytoparasitica, 3, 299-300.

- Hoddle M. S., Al-Abbad A. H., El-Shafie H.A.F., Faleiro J. R., Sallam A. A., Hoddle C. D. (2013). Assessing the impact of areawide pheromone trapping, pesticide applications, and eradication of infested date palms for Rhynchophorus ferrugineus (Coleoptera: Curculionidae) management in Al Ghowaybah, Saudi Arabia. Crop Protection, 53, 152-160.

- Hussain A., Rizwan-ul-Haq M., Al-Jabr A. M., Al-Ayied H. Y. (2013) - Managing invasive populations of red palm weevil: a worldwide perspective. Journal of Food Agriculture and Environment, 11 (2), 456-463. 
- Kaakeh W. (2005). Longevity, fecundity, and fertility of the red palm weevil, Rhynchophorus ferrugineus Olivier (Coleoptera: Curculionidae) on natural and artificial diets. Emir J agric sciences 17: 23-33

- Kaakeh W. (2006). Toxicity of imidacloprid to developmental stages of Rhynchophorus ferrugineus (Curculionidae: Coleoptera): laboratory and field tests. Crop Prot. 25, 432-439.

- Kehat M. (1999). Threat to date palms in Israel, Jordan and the Palestinian authority by the red palm weevil, Rhynchophorus ferrugineus. Phytoparasitica 27, 241-242.

- Llàcer E., Martìnez de Altube M. M., Jacas J. A. (2009). Evaluation of the efficacy of Steinernema carpocapsae in a chitosan formulation against the red palm weevil, Rhynchophorus ferrugineus in Phoenix canariensis. Biocontrol 54, 559-565.

- Llácer E., Dembilio O., Jacas J. A. (2010). Evaluation of the efficacy of an insecticidal paint based on chlorpyrifos and pyriproxyfen in a microencapsulated formulation against Rhynchophorus ferrugineus (Coleoptera: Curculionidae). Journal of Economic Entomology, 103 (2), 402-408.

- Llácer E., Negre M., Jacas J.A. (2012). Evaluation of an oil dispersion formulation of imidacloprid as a drench against Rhynchophorus ferrugineus (Coleoptera: Curculionidae) in young palm trees. Pest Manag. Sci. 68, 878-882.

- Lòpez J., Jimènez R., Mateo M. P., Moreno J., Oltra M. T. (1999). Efficacy of Inesfly 5A IGR paint against Periplaneta americana in sewers in Canary Islands (Spain). In: Proceedings of the 3rd International Conference on Urban Pests, 19-22 July 1999, Prague, Czech Republic (W. H. Robinson, F. Rettich, and G. W. Rambo coord.). Czech University of Agriculture, Prague, Czech Republic, p. 623.

- Mosqueira B., Finot L., Chabi J., Akogbeto M., Chandre F., Hougard J. M., Carnevale P., and Mas-Coma S. (2005). Evaluation of the efficacy of a new insecticide paint for Malaria control. In: Proceedings of the Medicine and Health in the Tropics Congress, 11-15 September 2004, Marseille, France, pp. 107-108, (http://www.festmih.eu/document/1146).

- Murphy S. T., Briscoe B. R. (1999). The red palm weevil as an alien invasive: biology and the prospects for biological control as a component of IPM. Biocontrol News Inf. 20, 35-46.

- Reginald C. (1973). Principal Insect Pests. In: Coconuts. Tropical Agriculture Series, London, UK, 68.

- Rettori A. A., Martinis R., Pugliese M., Al-Rohily K., Al-Maashi Al, Occhiello E., Gullino M. L. (2015). Use of tree stability assessment devices to detect red palm weevil infestation, submitted. 
- Salama, H. S.; Zaki, F. N.; Abdel-Razek, A. S. (2009). Ecological and biological studies on the red palm weevil Rhynchophorus ferrugineus (Olivier). Archives of Phytopathology and Plant Protection Vol. 42 No. 4 pp. 392-399.

- Vacante V. (2013) - Punteruolo rosso delle palme: aggiornamenti sulle tecniche di lotta. Protezione delle Colture, 6 (5), 38-51.

308

309

310

311 
313 Table 1 - Different treatments applied in the trials.

\begin{tabular}{|c|c|c|c|c|}
\hline Thesis & Coating & Solvent & Insecticide & Repellent \\
\hline $\mathrm{T} 1$ & Vinyl acetate $59(100 \mathrm{~g})$ & $38.7 \mathrm{~g} \mathrm{H} 2 \mathrm{O}$ & & 5 g Camphor White oil \\
\hline $\mathrm{T} 2$ & Vinyl acetate $59(100 \mathrm{~g})$ & $109.3 \mathrm{~g} \mathrm{H} 2 \mathrm{O}$ & $\begin{array}{c}40 \mathrm{~g} \text { Teflustar } \\
(0.08 \mathrm{~g} \text { teflutrin })\end{array}$ & 5 g Camphor White oil \\
\hline $\mathrm{T} 3$ & Vinyl acetate $59(100 \mathrm{~g})$ & $109.3 \mathrm{~g} \mathrm{H} 2 \mathrm{O}$ & $\begin{array}{c}20 \mathrm{~g} \text { Teflustar } \\
(0.04 \mathrm{~g} \text { teflutrin })\end{array}$ & 5 g Camphor White oil \\
\hline $\mathrm{T} 4$ & Vinyl acetate $59(100 \mathrm{~g})$ & $38.7 \mathrm{~g} \mathrm{H} 2 \mathrm{O}$ & & \\
\hline T5 & Vinyl acetate $59(100 \mathrm{~g})$ & $82.7 \mathrm{~g} \mathrm{H} 2 \mathrm{O}$ & $\begin{array}{c}30 \mathrm{~g} \text { Zelig GR } \\
(2.25 \mathrm{~g} \\
\text { chlorpyrifos) }\end{array}$ & 5 g Camphor White oil \\
\hline T6 & Vinyl acetate $59(100 \mathrm{~g})$ & $46.7 \mathrm{~g} \mathrm{H} 2 \mathrm{O}$ & $\begin{array}{c}15 \text { g Zelig GR } \\
(1.125 \mathrm{~g} \\
\text { chlorpyrifos) }\end{array}$ & 5 g Camphor White oil \\
\hline $\mathrm{T} 7$ & Raw Linseed oil $(100 \mathrm{~g})$ & $25 \mathrm{~g}$ Limonene & $\begin{array}{l}40 \mathrm{~g} \text { Teflustar } \\
(0.08 \mathrm{~g} \text { teflutrin })\end{array}$ & 5 g Camphor White oil \\
\hline $\mathrm{T} 8$ & Raw Linseed oil (100 g) & $25 \mathrm{~g}$ Limonene & $\begin{array}{l}.0420 \mathrm{~g} \text { Teflustar } \\
(0.08 \mathrm{~g} \text { teflutrin })\end{array}$ & 5 g Camphor White oil \\
\hline T9 & Raw Linseed oil $(100 \mathrm{~g})$ & $25 \mathrm{~g}$ Limonene & $\begin{array}{c}30 \text { g Zelig GR } \\
(2.25 \mathrm{~g} \\
\text { chlorpyrifos) }\end{array}$ & 5 g Camphor White oil \\
\hline $\mathrm{T} 10$ & Raw Linseed oil (100 g) & $25 \mathrm{~g}$ Limonene & $\begin{array}{c}15 \text { g Zelig GR } \\
(2.25 \mathrm{~g} 1.125 \\
\text { chlorpyrifos) } \\
\end{array}$ & 5 g Camphor White oil \\
\hline $\mathrm{T} 11$ & Raw Linseed oil $(100 \mathrm{~g})$ & $25 \mathrm{~g}$ Limonene & & \\
\hline $\mathrm{T} 12$ & Raw Linseed oil (100 g) & $25 \mathrm{~g}$ Limonene & & 5 g Camphor White oil \\
\hline $\mathrm{T} 13$ & \multicolumn{4}{|c|}{ Untreated control } \\
\hline
\end{tabular}


318 Table 2 - Evaluation of phytotoxicity of coating treatments on date and canary palms.

\begin{tabular}{|c|c|c|c|c|c|c|}
\hline \multirow{2}{*}{ Treatment } & \multicolumn{2}{|c|}{ CCI } & \multicolumn{2}{c|}{ Discouloration** } & \multicolumn{2}{c|}{ Necrosis** } \\
\cline { 2 - 7 } & $\begin{array}{c}\text { Phoenix } \\
\text { dactylifera }\end{array}$ & $\begin{array}{c}\text { Phoenix } \\
\text { canariensis }\end{array}$ & $\begin{array}{c}\text { Phoenix } \\
\text { dactylifera }\end{array}$ & $\begin{array}{c}\text { Phoenix } \\
\text { canariensis }\end{array}$ & $\begin{array}{c}\text { Phoenix } \\
\text { dactylifera }\end{array}$ & $\begin{array}{c}\text { Phoenix } \\
\text { canariensis }\end{array}$ \\
\hline T1 & $28.42 \pm 4.61 *$ & $53.37 \pm 15.52 \mathrm{a}$ & $0.00 \pm 0.00 \mathrm{a}$ & $0.00 \pm 0.00 \mathrm{a}$ & $0.20 \pm 0.42 \mathrm{a}$ & $0.50 \pm 0.53 \mathrm{a}$ \\
\hline T2 & $35.13 \pm 11.11 \mathrm{a}$ & $53.00 \pm 11.95 \mathrm{a}$ & $0.00 \pm 0.00 \mathrm{a}$ & $0.10 \pm 0.00 \mathrm{a}$ & $0.10 \pm 0.32 \mathrm{a}$ & $0.70 \pm 0.67 \mathrm{a}$ \\
\hline T3 & $34.53 \pm 8.78 \mathrm{a}$ & $45.37 \pm 10.46 \mathrm{a}$ & $0.00 \pm 0.00 \mathrm{a}$ & $0.10 \pm 0.32 \mathrm{a}$ & $0.00 \pm 0.00 \mathrm{a}$ & $0.40 \pm 0.52 \mathrm{a}$ \\
\hline T4 & $30.41 \pm 9.49 \mathrm{a}$ & $51.80 \pm 8.77 \mathrm{a}$ & $0.00 \pm 0.00 \mathrm{a}$ & $0.00 \pm 0.00 \mathrm{a}$ & $0.10 \pm 0.32 \mathrm{a}$ & $0.60 \pm 0.70 \mathrm{a}$ \\
\hline T5 & $38.27 \pm 9.53 \mathrm{a}$ & $44.85 \pm 15.13 \mathrm{a}$ & $0.00 \pm 0.00 \mathrm{a}$ & $0.00 \pm 0.00 \mathrm{a}$ & $0.00 \pm 0.00 \mathrm{a}$ & $0.10 \pm 0.32 \mathrm{a}$ \\
\hline T6 & $36.55 \pm 5.95 \mathrm{a}$ & $54.96 \pm 8.18 \mathrm{a}$ & $0.00 \pm 0.00 \mathrm{a}$ & $0.10 \pm 0.32 \mathrm{a}$ & $0.10 \pm 0.32 \mathrm{a}$ & $0.40 \pm 0.52 \mathrm{a}$ \\
\hline T7 & $39.43 \pm 7.54 \mathrm{a}$ & $46.26 \pm 11.01 \mathrm{a}$ & $0.00 \pm 0.00 \mathrm{a}$ & $0.10 \pm 0.32 \mathrm{a}$ & $0.00 \pm 0.00 \mathrm{a}$ & $0.40 \pm 0.70 \mathrm{a}$ \\
\hline T8 & $41.78 \pm 8.57 \mathrm{a}$ & $52.38 \pm 9.97 \mathrm{a}$ & $0.00 \pm 0.00 \mathrm{a}$ & $0.10 \pm 0.32 \mathrm{a}$ & $0.00 \pm 0.00 \mathrm{a}$ & $0.40 \pm 0.52 \mathrm{a}$ \\
\hline T9 & $38.09 \pm 10.17 \mathrm{a}$ & $52.32 \pm 10.64 \mathrm{a}$ & $0.00 \pm 0.00 \mathrm{a}$ & $0.00 \pm 0.00 \mathrm{a}$ & $0.00 \pm 0.00 \mathrm{a}$ & $0.10 \pm 0.32 \mathrm{a}$ \\
\hline T10 & $43.29 \pm 10.83 \mathrm{a}$ & $53.82 \pm 13.16 \mathrm{a}$ & $0.00 \pm 0.00 \mathrm{a}$ & $0.30 \pm 0.42 \mathrm{a}$ & $0.10 \pm 0.32 \mathrm{a}$ & $0.70 \pm 0.67 \mathrm{a}$ \\
\hline T11 & $39.79 \pm 10.22 \mathrm{a}$ & $48.25 \pm 12.70 \mathrm{a}$ & $0.00 \pm 0.00 \mathrm{a}$ & $0.00 \pm 0.00 \mathrm{a}$ & $0.00 \pm 0.00 \mathrm{a}$ & $0.50 \pm 0.53 \mathrm{a}$ \\
\hline T12 & $41.73 \pm 8.45 \mathrm{a}$ & $50.54 \pm 12.81 \mathrm{a}$ & $0.00 \pm 0.00 \mathrm{a}$ & $0.10 \pm 0.32 \mathrm{a}$ & $0.00 \pm 0.00 \mathrm{a}$ & $0.50 \pm 0.53 \mathrm{a}$ \\
\hline Control & $32.65 \pm 7.01 \mathrm{a}$ & $58.11 \pm 15.33 \mathrm{a}$ & $0.00 \pm 0.00 \mathrm{a}$ & $0.00 \pm 0.00 \mathrm{a}$ & $0.10 \pm 0.32 \mathrm{a}$ & $0.30 \pm 0.42 \mathrm{a}$ \\
\hline $\begin{array}{c}\text { Total } \\
\text { average }\end{array}$ & $\mathbf{3 6 . 9 3} \pm 9.48$ & $\mathbf{5 1 . 1 6} \pm \mathbf{1 2 . 2 1}$ & $\mathbf{0 . 0 0 \pm 0 . 0 0}$ & $\mathbf{0 . 0 7} \pm \mathbf{0 . 2 3}$ & $\mathbf{0 . 0 5 3 8} \pm \mathbf{0 . 2 2}$ & $\mathbf{0 . 4 3} \pm \mathbf{0 . 5 5}$ \\
\hline
\end{tabular}

* Tukey's HSD $(\mathrm{p} \leq 0.05)$

**Discolouration/necrosis of leaves, scale: $0=$ no symptoms; $1=$ light leaf chlorosis/necrosis; $2=$ leaf chlorosis/necrosis up to $25 \% ; 3=26-50 \%$ leaf chlorosis/necrosis; $4=51-90 \%$ leaf 
Table 3 - Efficacy evaluation of coating treatments on date and canary palms, after 400 days. Infested palms were calculated as percentage, where healthy palm corresponds to 0 and infested palm to 100 .

\begin{tabular}{|c|c|c|c|c|}
\hline \multirow{2}{*}{ Treatment } & \multirow{2}{*}{$\begin{array}{l}\text { Valid } \\
\text { cases }\end{array}$} & Phoenix dactylifera & Phoenix canariensis & Average \\
\cline { 3 - 5 } & 22 & $13.63 \pm 7.49 \mathrm{ab} *$ & $9.09 \pm 6.27 \mathrm{ab}$ & $11.36 \pm 4.84 \mathrm{bc}$ \\
\hline T1 & 22 & $0 \pm 0 \mathrm{a}$ & $9.09 \pm 6.27 \mathrm{ab}$ & $4.54 \pm 3.17 \mathrm{ab}$ \\
\hline T2 & 22 & $4.54 \pm 4.54 \mathrm{ab}$ & $9.09 \pm 6.27 \mathrm{ab}$ & $4.83 \pm 3.84 \mathrm{ab}$ \\
\hline T3 & 22 & $4.54 \pm 4.54 \mathrm{ab}$ & $22.73 \pm 9.14 \mathrm{~cd}$ & $13.64 \pm 5.23 \mathrm{bc}$ \\
\hline T4 & 22 & $0 \pm 0 \mathrm{a}$ & $0 \pm 0 \mathrm{a}$ & $0 \pm 0 \mathrm{a}$ \\
\hline T5 & 22 & $0 \pm 0 \mathrm{a}$ & $0 \pm 0 \mathrm{a}$ & $0 \pm 0 \mathrm{a}$ \\
\hline T6 & 22 & $0 \pm 0 \mathrm{a}$ & $9.09 \pm 6.27 \mathrm{a}$ & $4.54 \pm 3.18 \mathrm{ab}$ \\
\hline T7 & 22 & $9.09 \pm 6.27 \mathrm{ab}$ & $9.09 \pm 6.27 \mathrm{a}$ & $9.09 \pm 4.38 \mathrm{bc}$ \\
\hline T8 & 22 & $9.09 \pm 6.27 \mathrm{ab}$ & $9.09 \pm 6.27 \mathrm{a}$ & $9.09 \pm 4.38 \mathrm{bc}$ \\
\hline T9 & 22 & $4.54 \pm 4.54 \mathrm{ab}$ & $9.09 \pm 6.27 \mathrm{ab}$ & $6.82 \pm 3.84 \mathrm{ab}$ \\
\hline T10 & 22 & $36.36 \pm 10.50 \mathrm{c}$ & $13.64 \pm 7.49 \mathrm{bc}$ & $25.00 \pm 6.60 \mathrm{~cd}$ \\
\hline T11 & 22 & $22.73 \pm 9.14 \mathrm{bc}$ & $22.73 \pm 9.14 \mathrm{~cd}$ & $22.73 \pm 6.39 \mathrm{~cd}$ \\
\hline T12 & 22 & $59.09 \pm 10.73 \mathrm{c}$ & $36.36 \pm 10.50 \mathrm{~d}$ & $47.73 \pm 7.62 \mathrm{e}$ \\
\hline CONTROL & & &
\end{tabular}

$$
\text { * Tukey's HSD }(\mathrm{p} \leq 0.05)
$$

Table 4 - Efficacy evaluation of treatments 1-4 (vinyl acetate without insecticide), 2-3-5-6 (vinyl acetate with insecticide), 7-8-9-10 (Raw Linseed oil with insecticide), 11-12 (Raw Linseed oil without insecticide) and control comparison on date and canary palms, after 400 days. Infested palms were calculated as percentage, where healthy palm corresponds to 0 and infested palm to 100.

\begin{tabular}{|c|c|c|c|}
\hline \multirow{2}{*}{ Treatment } & Phoenix dactylifera & Phoenix canariensis & Average \\
\cline { 2 - 4 } & \multicolumn{2}{|c|}{ \% of healthy palms } \\
\hline $\begin{array}{c}\text { T2-T3-T5-T6 (vynil acetate } \\
\text { based products with insecticide) }\end{array}$ & $1.14 \pm 1.14 \mathrm{a}^{*}$ & $4.54 \pm 2.23 \mathrm{ab}$ & $2.84 \pm 1.25 \mathrm{a}$ \\
\hline $\begin{array}{c}\text { T1-T4 (vynil acetate based } \\
\text { products without insecticide) }\end{array}$ & $9.09 \pm 4.38 \mathrm{a}$ & $15.91 \pm 5.58 \mathrm{ac}$ & $12.50 \pm 3.54 \mathrm{~b}$ \\
\hline $\begin{array}{c}\text { T7-T8-T9-T10 (Raw Linseed } \\
\text { based products with insecticide) }\end{array}$ & $5.68 \pm 2.48 \mathrm{a}$ & $9.09 \pm 3.08 \mathrm{ab}$ & $7.39 \pm 1.98 \mathrm{ab}$ \\
\hline $\begin{array}{c}\text { T11-T12 (Raw Linseed based } \\
\text { products without insecticide) }\end{array}$ & $29.54 \pm 6.95 \mathrm{~b}$ & $18.18 \pm 5.88 \mathrm{c}$ & $23.86 \pm 4.57 \mathrm{c}$ \\
\hline Control & $59.09 \pm 10.73 \mathrm{c}$ & $36.36 \pm 10.49 \mathrm{~d}$ & $47.73 \pm 7.62 \mathrm{~d}$ \\
\hline
\end{tabular}


* Tukey's HSD $(\mathrm{p} \leq 0.05)$

Table 5 - Percentage of infested palms related to products and insecticides

\begin{tabular}{|c|c|c|c|c|c|c|c|c|c|}
\hline & & $\begin{array}{c}110 \\
\text { days }\end{array}$ & $\begin{array}{c}152 \\
\text { days }\end{array}$ & $\begin{array}{c}180 \\
\text { days }\end{array}$ & $\begin{array}{c}210 \\
\text { days }\end{array}$ & $\begin{array}{c}245 \\
\text { days }\end{array}$ & $\begin{array}{c}285 \\
\text { days }\end{array}$ & $\begin{array}{c}323 \\
\text { days }\end{array}$ & $\begin{array}{c}400 \\
\text { days }\end{array}$ \\
\hline \multirow{2}{*}{$\begin{array}{c}\text { Vinyl } \\
\text { acetate }\end{array}$} & & $0,0 \%$ & $0,0 \%$ & $0,0 \%$ & $0,0 \%$ & $0,0 \%$ & $1,1 \%$ & $1,7 \%$ & $2,8 \%$ \\
\hline & without insecticide & $2,3 \%$ & $2,3 \%$ & $3,4 \%$ & $3,4 \%$ & $4,5 \%$ & $5,7 \%$ & $10,2 \%$ & $12,5 \%$ \\
\hline \multirow{2}{*}{$\begin{array}{c}\text { Raw } \\
\text { Linseed Oil } \\
\end{array}$} & with & $0,0 \%$ & $0,0 \%$ & $0,0 \%$ & $0,0 \%$ & $0,0 \%$ & $1,1 \%$ & $1,1 \%$ & $7,4 \%$ \\
\hline & without insecticide & $3,4 \%$ & $5,7 \%$ & $8,0 \%$ & $9,1 \%$ & $12,5 \%$ & $15,9 \%$ & $18,2 \%$ & $23,9 \%$ \\
\hline Control & & $6,8 \%$ & $6,8 \%$ & $9,1 \%$ & $15,9 \%$ & $22,7 \%$ & $29,5 \%$ & $38,6 \%$ & $47,7 \%$ \\
\hline
\end{tabular}

Table 6 - Percentage of infested palms related to insecticides.

\begin{tabular}{|clc|c|c|c|c|c|c|c|}
\cline { 3 - 8 } & & $\begin{array}{c}\mathbf{1 1 0} \\
\text { days }\end{array}$ & $\begin{array}{c}\mathbf{1 5 2} \\
\text { days }\end{array}$ & $\begin{array}{c}\mathbf{1 8 0} \\
\text { days }\end{array}$ & $\begin{array}{c}\mathbf{2 1 0} \\
\text { days }\end{array}$ & $\begin{array}{c}\mathbf{2 4 5} \\
\text { days }\end{array}$ & $\begin{array}{c}\mathbf{2 8 5} \\
\text { days }\end{array}$ & $\begin{array}{c}\mathbf{3 2 3} \\
\text { days }\end{array}$ & $\begin{array}{c}\mathbf{4 0 0} \\
\text { days }\end{array}$ \\
\hline \multirow{2}{*}{ Teflutrin } & Vinyl acetate & $0,0 \%$ & $0,0 \%$ & $0,0 \%$ & $0,0 \%$ & $0,0 \%$ & $2,3 \%$ & $3,4 \%$ & $5,7 \%$ \\
& Raw Linseed Oil & $0,0 \%$ & $0,0 \%$ & $0,0 \%$ & $0,0 \%$ & $0,0 \%$ & $1,1 \%$ & $1,1 \%$ & $6,8 \%$ \\
\hline \multirow{2}{*}{ Chlorpyrifos } & Vinyl acetate & $0,0 \%$ & $0,0 \%$ & $0,0 \%$ & $0,0 \%$ & $0,0 \%$ & $0,0 \%$ & $0,0 \%$ & $0,0 \%$ \\
& Raw Linseed Oil & $0,0 \%$ & $0,0 \%$ & $0,0 \%$ & $0,0 \%$ & $0,0 \%$ & $1,1 \%$ & $1,1 \%$ & $8,0 \%$ \\
\hline
\end{tabular}

